\title{
SEVENTEENTH-CENTURY ENGLISH NEWSPAPERS AND PERIODICALS
}

\author{
BY VIRGINIA S. BURNETT
}

No old NEwSPAPER can steal into the Rutgers Library unobserved by Miss Burnett and, fortunately, none is likely to find a way out past her watchful eye. In addition to her work with the newspaper files of the Library, Miss Burnett has been active in the work of the New Brunswick Historical Club. She has also begun publication of the records of early gravestones in the Presbyterian churchyard in Morristown.

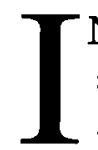

$\mathbf{N}$ the bibliography of seventeenth-century English newspapers and periodicals which follows, the complete title entry given has always been taken from the first number that is to be found in the collection in the Rutgers University Library. In the case of title changes, those sufficient to affect the alphabetical arrangement of the list have been entered separately. The frequency of publication and the period of existence have been given following the title entry whenever they have been known or ascertained from two or more sources. When the place of publication has not been given, London is to be understood. Unless otherwise stated, the numbers listed are the original issues. Incomplete numbers are enclosed in brackets. Dates have been uniformly expressed in New Style. Issues dated for a period of time instead of with a single date (e.g. Thurs. Aug. I to Thurs. Aug. 8) have been given only the latter date (e.g. Aug. 8). A question mark after a date means that the date is inferential.

Anti-aulicus. Discovering weekly the policies, deceits, and erroneous maximes of the Court: And informing the people of their cause, interest, and whatsoever he conceives will advantage the same; as Aulicus shall give occasion in his weekly pamphlet. w. 1644//?

Nos. 1-2, Feb. 6, 8, 1644. Photostat copies

Colophon: Printed according to order, for H.T. [i.e. Humphrey Toy] Announcement made in No. I: "Had not some hinderance interveen'd, this had come forth the last Weeke; but now look for a second upon Thursday, and a third upon Tuesday next; and so weekly every Tuesday one."

Written in long-hand, on No. I: "Tuesday ye 6th ffebruary I643," and on No. 2: "Thursday 8th feb. 1643."

The first issue is unnumbered. 
Slight variation in sub-title, No. 2: Omission of the word "cause"; substitution of "weekely" for "weekly."

Entered in S.R., ${ }^{1}$ I, 98: "Hum. Toy. Entred . . . under the hand of Henry Walley."

The Anti-Roman pacquet: or, Memoirs of popes and popery, for the conviction of Papists, and confirmation of Protestants. w.

Nos. 5-[7]-2 I, Aug. 6-Nov. 26, 1680.

Colophon: Printed for L. C. [Langley Curtiss] (Nos. 5-7); Printed by A. Godbid for L.C. (Nos. 8-2I).

Slight variation in sub-title, No. 5: Substitution of "satisfaction" for "confirmation."

The last leaf of each issue contains a section, unnumbered and undated, with caption-title: The Popes harbinger, by way of diversion (Nos. 5-I 5, I7-18, 2I ); The Popes harbinger, that the Hereticks may know what they are to trust to ... (No. 16); The Popes harbinger (Nos. 19-20).

Supersedes The New anti-Roman pacquet ... [q.v.] (from No. 5)

Superseded by The Weekly pacquet of advice from Rome ... [q.v.] (from No. 22)

The Armies scout. Impartially communicating to the people, the faithful proceedings of the Lord General and his council of officers; the most remarkable passages at sea, between the English and Dutch fleets; and the most notable occurrences from Holland, France, Spain, Denmark, Sweden, and the king of Scots. Licensed according to the directions of the late act for printing. London, Printed by Robert Wood. w. Nos. II4-II9, Ap 30-Je 3, 1653/

No. 114, April 30, 1653. Photostat

Supersedes and is superseded by The Faithful scout . . .

The Best and most perfect intelligencer: the summe of all remarkable affaires now prosecuted in the three nations of England, Scotland, and Ireland, impartially narrated, especially from Scotland. Published by William Huby. No. I, $A g$ I $/ 8$, I650//?

No. I, August 8 , 1650. Photostat

Announcement in issue: "This is the first day of my discoverie; give me your hands, my deare Brethren of the Waste-Paper Fraternitie: I shall not indevour to heighten Dissention, or to foment Discord; onely perfect and impartiall Intelligence shall be the Asylum of my wishes: and if any finde I runne in typos, quasi in Scippos, I shall desire him

\footnotetext{
1 This abbreviation will be used throughout in referring to the Stationers' Registers.

2 For life-span and history of this periodical, sce entry: The Weekly pacquet of advice from Rome...
} 


\section{Mercurius Publicus:}

\section{COMPRISIN $G$ \\ The Sum of Forraign Intelligence;}

W ITH

The Affairs now in Agitation in England, Scotland, and Ireland.

For Information of the People.

Publiphed by Order of the Couscil of state.

From Thurfday M-y 10, to Thurfday Mag 17, 1660; *

Oxon, May 10. 1660.

His day the King was proclaimed here in a very folcmn, magnificent, splendid, and joyful order, the manner thus; Yefierday in the cvening, the Mayor received the Proclamation for proclaiming of the Xing immediately, whereon be furnmesid a Ccmmon. Council to convene this morning, where tie m. ancr of the Solemnity being agreed on, it was orde: d thicy fhould all meet at the Guild-hall at two a clock aficincou, from whence the 
not to castigate me more strenuously then the rest of he Renowned Inkesquirters: and so I proceed to Intelligence."

Britanicus Vapulans: or the whipping of poore British mercury, set out in a letter directed to him from Mercurius Urbanus, younger brother to Aulicus. w.

No. I, [Nov. 4, 1643] Photostat

No imprint

Written in long-hand: "Novemb: $4^{\text {th }} 1643$ "

Note on p. 8 of issue: "And so farwell, and remember next week not to misse the advantage of my Title and to call me Pope Urban."

Certaine speciall and remarkable passages from both Houses of Parliament. London, Printed for Francis Leach and Francis Coles, 1642. No. I, Aug. 26, I642. Photostat

This issue is unnumbered.

Cheife (sic.) heads of each dayes proceedings in Parliament. And most meteriall collections of some letters, messuages, and other reports . . . London, Printed by Francis Leach. (No. I) My 8/15, 1644//?

No. I, May I5, [1644] Photostat

Colophon: This is printed according to Order.

This issue is unnumbered.

Written in long-hand: "till $155^{\text {th }}$ I644."

Entered in S.R., I, I I5: "Master Walbanck. Entred . . under the hand of Master Rushworth."

The Compleate intelligencer and resolver, communicating the affaires from Scotland, from Court, and other places, with some necessary resolutions to be considered by all that desire satisfaction. w. Nos. I-5, Nov. $2-28,1643 / /$

No. I, Nov. 2, 1643. Photostat

In upper left-hand corner of title-page: "Intelligence and resolution." Colophon: This is licensed and entered according to order.

This issue is unnumbered.

Entered in S.R., I, 86: "Hum. Blunden. Entred ... under the hand of Henry Walley ..."

A Continuation of certaine speciall and remarkable passages from both Houses of Parliament, and divers other places of the kingdome. Printed for Robert Wood, I642. Nos. I-52, Sep 22, I642-Je 16, I643//?

No. 13, Oct. 8, 1642. Photostat

Colophon: October 8. printed for Robert Wood, 1642.

A Continuation of certaine speciall an (sic.) remarkable passages informed to 
the Parliament, and otherwise from divers parts of this kingdome. London, Printed for F. L. [Francis Leach] Nos. I- , Sep I9/26, 1645F 27, 1646//

No. I, Sept. 26, I645. Photostat

Entered in S.R., I, 195: "Francis Leech. Entred for his copie under the hand of Master Mabbott deputy to Master Rushworth ..."

A Continuation of the proceedings in Scotland. Licensed and entered according to order.

No. 77 , Dec. 10, 1689.

Colophon: London: Printed for Richard Chiswell, at the Rose and Crown in St. Paul's church-yard. 1689.

Continued heads of perfect passages in Parliament and proceedings of the Councell of state, and the army. From Friday 13 Aprill. to Friday the 20. of Aprill 1649. Imprimatur Theodore Jennings, 19 Aprill 1649. Printed at London for Andrew Coe, and are to be sold without Creplegate, and in the Old-Bayley. 1649. w. Nos. 1-5, Ap 13/20My I I/1 8, I649//

No. I, April 20, 1649. Photostat

Corant or weekly newes, from Italy, Germany, Hungaria, Polonia, Bohemia, France, and the Low-countries.

October I I, I62I. Photostat

This issue is unnumbered.

Colophon: Printed for N.B. [Nathaniel Butter] October the I1. I621. Out of the Low Dutch coppy.

A Coranto from beyond sea: or, True intelligence from France, Spain, Germany, and Denmark. Being severall expresses sent from those parts to the Right Honorable, The Earl of Warwick. London: Printed for Humphrey Tuckey; June 9. I643. No. I, Je 9, 1643//?

No. I, June 9, 1643. Photostat

$?$ The Countrey foot-post: faithfully communicating his intelligence from the severall parts of the Kingdome; and from beyond the seas. [4 lines] Published by Authority: and printed for G.B. and T.B. Octo. 2, I644. No. 1, Oct. 2, 1644. Photostat

Superseded by The Countrey messenger [q.v.] (from no. 2)

The first, paragraph indicates this is a revival as the author states: "Without any long Apology, the Intelligence presented unto you here, is Faithfull and true, and written by one, who hath heretofore given good content in this kind. To revive it again, your favourable acceptance will give encouragement for the future." 
The Countrey messenger, or the faithfull foot-post communicating his weekly intelligence from the severall parts of the kingdome; and from beyond the seas. [3 lines]

No. 2, Oct. I I, 1644 . Photostat

Colophon: Printed according to Order, by G. Bishop, Octob. I1. 1644. This is a continuation of The Countrey foot-post [q.v.]

The Daily intelligencer of court, city, and countrey, relating the most remarkable passages in either, which may save much labour in writing of letters. ... London, Printed for Ioh Thompson, Ian 30. Anno Dom. 1643. No. 1, Jan. 30, 1643. Photostat

The Daily proceedigs (sic.) of the armies by sea and land, under the command of his Excellency the Lord General Cromwel. Containing the truest intelligence from all parts of England, Scotland, Ireland, Holland, Denmark, Sweden, France, and divers other places, shewing the present state of things. Appointed by authority from the army to be printed, for the true information of the people of this nation.

[June 1653]. Photostat

No imprint.

Written in long-hand: "June $17.1653 . "$

This issue is unnumbered and undated, but an examination of it reveals a letter in the text dated "June 22, 1653." Therefore the date of publication must have been later than June 17 th, although it has been accepted by bibliographers.

Dawks's news-letter. $S^{r}$. London. tri-w. 1696?-1 7 16?

June 13. 1699. Photostat

Colophon: This letter contains whatever is material in all the other News Papers, to which is added the Occurrences of the day, it not being published till between 4 and 5 in the evening on post nights, and may be had for ten shillings a quarter of I. Dawks, [Ichabod Dawks] in Wardrobe Court in Great Carter Lane, near the West end of St. Pauls.

This issue is unnumbered.

Printed in script type to imitate writing.

A Declaration, collected out of the journalls of both Houses of Parliament. And some passages concerning the king, the army, city and kingdome. w. Nos. 1-3, N 29/D6-D20, 1648//

No. 1, Dec. 6, 1648. Photostat

Colophon: London Printed by Robert Ibbitson in Smithfield near the Queens head tavern, 1648. 
The Diary, being a perfect summary of the particular proceedings of our armies in England, Ireland, and Scotland; as also of our fleets at sea. Together with the Orders of Parliament and the councel of state in relation thereunto. [2 lines]. London, Printed by Bernard Alsop, I65I.

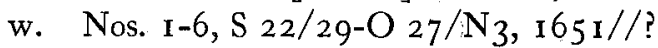

No. I, Sep. 29, I651. Photostat

The Diurnall occurrances in Parliament . . . : Contayning the Scotch commisioners desires to the king, and the order of the House of Commons thereupon, and many other particular passages concerning Ireland. Much bloud was shed but the Scott ${ }^{8}$ got the day, and obtained the victory. Also many other remarkable occurrance truely and exactly set downe. Printed for F. Coules, and T. Banks. I64I (i.e. I642).

No. 2, Jan. 24, I642. Photostat.

The Diurnall occurrences in Parliament.

June 6, 1642. Photostat

No imprint.

Issue is unnumbered.

'. England's memorable accidents. S 5/12, I642-Ja I6, I643//

No. 2, Sept. I 9, I642. Photostat

Colophon: London, Printed for Stephen Bowtell in Popes head alley, 1642.

Englands remembrancer of Lodons (sic.) integritie. Or Newes from London: Of which all that fear God or have any desire of the peace and safety of this kingdome ought to be truely informed. Nos. I-, Ja I4, I647-O I $2,1649 / /$.

No. I, Jan. I4, 1647. Photostat

Colophon: London, Printed by John Macock, for Thomas Underhil, and are to be sold at his shop in Woodstreet. 1647.

Written in long-hand: "Jan. I $4^{\text {th }} 1646 . "$

Entered in S.R., I, 259: "Tho. Underhill. Entred ... under the hand of Master Cranford ..."

The English courant. semi-w. Nos. 1-2, My 25-25/29, I695//?

Nos. I-2, May 25, 29, I695. Photostat copies

Colophon: No. I: London, Printed for the author, and published by John Whitlock near Stationers-Hall. I695; No. 2: London, Printed for the author, and sold by John Whitlock near Stationers-hall. I695.

Heading on No. I: "To be Published every Wednesday and Saturday, and to contain an Impartial Collection of such Foreign and Domestick Occurrences, as shall arrive or happen betwixt the said Days, with 
other matters worth observation, and of Publick use and advantage, not only to the curious and speculative, but also to the Trading part of Mankind."

An exact diurnall faithfully communicating the most remarkable proceedings in both Houses of Parliament. As also delivering true intelligence from all the armies within His Majesties Dominions. With many other remarkeable passages both by sea, and land. Printed for Matthew Walbanke, at Grayes-Inne Gate. w. My 15/22, 1644- Mr 5, 1646//

No. I, May 22, I644. Photostat

Colophon: This is printed according to Order.

Continued as The Diary; or An exact journall ... (with no. 2).

The Exchange intelligencer. Imparting chiefly such domestique and forraine newes, as have not been mentioned at all, or which are not fully related by others. From France, Rome, Germany, Denmarke, Flaunders, and our owne kingdome, \&c. w. Nos. I-8, My I5-J1 I 8, I645//

No. I, May 15, 1645. Photostat

Colophon: London, Printed according to order, by T. Forcet.

Paragraph one is of such interest that it is quoted in part: "Wee had (some yeares agone) no Diurnals of our owne affaires in England. We did live then in so blessed a Time, that wee were onely curious, and desirous to heare forraigne Newes, and to know the state of other Kingdomes and Nations. And now by a strange alteration and vicissitude of Times wee talke of nothing else, but of what is done in England: and perhaps once in a fortnight, we hearken after Newes out of Scotland. It is true our owne Domestique affaires are of a greater concernment, then forraigne businesses; but yet, we may looke farther than home; partly to comfort us when we heare that although our neighbours are not imbroyled with Civill warres as we are: yet they are so wel imployed and so farre ingaged by their interests and pretences one against another, that they cannot very well frame any grand designe against us. Moreover, according as our severall inclinations and interests move us to rejoyce for the good success or to sorrow for the disasters that happen to our friends we desire to have some intelligence by which we may heare either of their welfare, or ill fortunes. Besides, it is requisite for Marchants, and for those that travell beyond Sea, or upon the Sea, to know (as neere as intelligence can be given) what forces are upon the Seas, and where the Armies quarter, that they may prevent many dangers, shun the meeting of foes, and seeke to joyne with their friends. These reasons have moved me to undertake this Weekly labour for the delight and profit of whom it may concerne ..." 
The Flying post [cut] Conveying weekly packets to all forraigne nations, of the proceedings of both Houses of Parliament, and the armies in Great Brittain. Published, for the cleer satisfaction of all forraigners and others who desire certain, and weekly information. w. $1644 / /$

No. I, May 10, I644. Photostat

Colophon: Published according to Order. May Io. London, Printed for Bernard Alsop. I644.

Announcement in issue: "The too too many errours committed of late time, by the irregularitie of the Presse, (which since by the wisedome of the Parliament, is in a great measure suppressed) which did run Weekly in severall channels to the greatest part of Europe, in great dishonour to our English Nation; Have enforced this my Flying Post never to make stay, till it had intimated the same unto you, and fully vindicated this my Native Kingdome, by publishing a certain Weekly Intelligence of all Proceedings of our honourable Parliament. . .."

The Harlem currant.

No. 2, Feb. 19, 1689. Photostat

Colophon: London Printed for Daniel Search, near White-Fryers-Gate in Fleet-street.

No. I, Feb. 14, I689 was issued as The Harllum currant.

Heads of some notes of the Citie Scout: communicating the affaires of the army, to the citie and kingdome. London printed, (sic.) by R. A. and Jane Coe. I645. w. Nos. I-I6, Jl 29-N I I, I645//

No. I0, Sept. 30, 1645. Photostat

Colophon: Printed, and published according to Order.

Inside title: The Citie Scout; communicating the affaires of the armie, to the city and kingdome. This title was employed altogether from No. I I, Oct. 7, I645.

Entered in S.R., I, I 96: "Rob ${ }^{\text {te }}$ Austen. Entred ... under the hand of Master Mabbott, deputy to Master Rushworth ..."

Heraclitus ridens: or, A discourse between jest and earnest, where many a true word is spoken in opposition to all libellers against the government. w. Nos. I-82, F I, I68I-Ag 22, 1682//.

Nos. I, I2-13, Feb. I; April 19-26, I68 I.

Colophon: London: Printed for the use of the people: Tuesday, Feb. I, I68I ; (Nos. 12-13): London, Printed for B. Tooke, I68I.

Continued as: Heraclitus ridens: at a dialogue between jest and earnest, concerning the times (from No. 2, Feb. 8, 168I).

Hermes straticus: or, A scourge for Elencticus and the Royall pamphleteers [4 lines]. No. $1, A g ~ 17,1648 / /$. 
No. 1, Aug. 17, 1648. Photostat

No imprint.

The Intelligencer, published for satisfaction and information of the people. With Privilege. w. Ag 31, I663-Ja 29, I666//.

Nos. 25, 41, March 28; May 23, 1664.

Colophon: London, Printed by Richard Hodgkinson, living in Thamesstreet over against Baynards-Castle, 1664 .

Edited by Sir Roger L'Estrange who, in 1663 , was assisted by Joseph Williamson (under-secretary and afterwards secretary of state). L'Estrange created a newspaper monopoly during his term as surveyor of the imprimery and printing presses.

This paper was supplemented by The Newes which was issued each Thursday from 3 Sept. 1663 to 21 Dec. 1663 as a separate paper. The two were correlated after no. 18 (Intelligencer, 28 Dec. 1663; Nerves, 3I Dec. I663), the numbering and pagination of the two made continuous, beginning again with no. I, page I. The Intelligencer continued to appear on Mondays and The Newes on Thursdays, the former having the odd numbers and the latter even numbers. L'Estrange made an attempt to replace The Intelligencer by issuing a Publick Intelligence on Tuesday, 28 Nov. 1665, without success. ${ }^{3}$

Irelands true diurnall, or A continued relation of the cheife (sic.) passages that have happened there since the IIth. of January unto this present. Sent from an Alderman of Dublin to his Sonne now resident in London. As also a letter sent from thence by the Deane of Ardagh to a friend of his in Dublin. Published by the importunity of divers friends in London, and for the truth thereof may give satisfaction to this kingdome. London, Printed for William Bladen, and are to be sold by Richard Rayston, in Ivie-lane. I64I (i.e. I64I-I642). Nos. I-2, Ja II/F3-Mar $1642 / /$. Jan. II-[Feb. 3], I642. Photostat

Note: "Feb. 3 " is not given alone as the date of this issue because it appears only in the text of the issue and not on the usual date line.

Continued as: $A$ True diurnall; or, A Continued relation of Irish occurrences (No. 2).

The Kingdomes intelligencer of the affairs now in agitation in England, Scotland, and Ireland: together with foraign intelligence: To prevent false newes. Published by authority. w. D 3I, 1660/Ja 7, I66I-Ag $3 \mathrm{I}, \mathrm{I} 663 / /$.

Vol. I, Nos. I, [4]-6, 8-9, I2-I 4, [ I8]-I9, 21, 29, [45], Jan. 7, Jan. 28-

${ }^{8}$ See British Museum. Catalogue of Printed Books: Periodical Publications. London, 1899. Pt. III, 812, and Huntington Library Bulletin, No. 2 (Nov. 1931), 17-18. 
Feb. 11, Feb. 25-Mar. 4, Mar. 25-Apr. 8, May 6-13, 27, July 22, Nov. II, I66I.

Vol. II, Nos. 1-[2-3]-[7], 9-I0, I 7, Jan. 6-Feb. I 7, Mar. 3-10, April 28, 1662.

Colophon: London, Printed by R. Hodgkinson, and Tho. Newcomb, I66 I (No. I) ; Printed by R. Hodgkinsonne (Nos. 5-9); Printed by Richard Hodgkinson, living in Thames-Street over against Baynards Castle (Nos. I 2-2 I) ; Printed by Da. Maxwell, Living in ThamesStreet, near Baynards-Castle (No. 29); Vol. II: Printed by Richard Hodgkinson, living in Thames-street over against Baynards Castle (Nos. 1-17).

Edited by Henry Muddiman and Giles Drury.

Issue of April 28, I662 is marked "No. I" for "No. I 7."

Supersedes Parliamentary Intelligencer as announced in the issue of Jan. 7, I66I, Vol. I, No. I: "We must begin this New-Year with the last day of the Old, if it be but to tel the Reader that the Parliamentary Intelligencer (as he has good reason) hath changed his name; the Parliament it self (from whom he borrow'd that Compellation) being now dissolved, though 'tis not in the power of Malice or Folly to misname that Parliament, since his Majesty hath pleased with His own Sacred Lips, to bid us call it the Healing and the Blessed Parliament." Title variation: Substitution of "Kingdoms" for "Kingdomes" in Nos. 5, 29, 45 of Vol. I for 166I. The substitution was carried for the remainder of the periodical's existence.

The Kingdomes weekly post, faithfully communicating the affaires of the armies to the kingdome.

Oct. 15, [1645]. Photostat

Colophon: Printed according to order by I. H. Octob. I 5 .

This issue is unnumbered and is without a yearly date.

Entered in S.R., I, I 98: "John Hamond. Entred . . under the hand of Master Mabbott deputy to Master Rushworth ..."

Most works examined attribute this paper to John Harris, but in the light of the above entry, that would seem to be incorrect.

The London gazette. Published by authority. semi-w. Feb. 5, I666+. (from No. 24)

Nos. 129, [213], Feb. I1, Dec. 2, 1667; No. 247, Mar. 30, 1668; Nos. 327, 378, 398, Jan. 4, July I, Sept. 9, 1669; No. 691, July 4, I672; No. 772, Apr. 14, 1673; No. 9 I I, Aug. 13, 1674; No. 1020, Aug. 30, I675; No. I09 I, May 4, 1676; No. I 203, May 31, I677; No. 1336, Sept. 9, I678; No. I427, July 24, 1679; Nos. I632, I68 I, July I I, Dec. 29, I681; No. 1778, Dec. 4, I682; No. 1835, June 21, I683; 
No. 1926, May 5, 1684; Nos. 2009-2039, 2041-2088, 2090, Feb. I9June 4, June I I-Nov. 23, Nov. 30, I685; Nos. 2319-2320, 2322-23, $2325, \quad 2327-2330, \quad 233^{2-2} 336, \quad 2339, \quad 2341-2347, \quad 2349-2378$, $2380-2385,2388-2392,2394,2396-2398,2401,2409,2416-$ 2417, Feb. 9-13, 20-23, Mar. I, Mar. 8-19, 26-Apr. 9, Apr. I9, 26-May 17, May 24-Sept. 3, 10-27, Oct. 8-22, 29, Nov. 5-12, I9, Dec. I3, 1688; Jan. 7, 10, 1689; No. 2576, July 21, 1690; No. 2652, Apr. I3, I691; No. 2796, Aug. 29, 1692; No. 2887, July 1 3, I693; No. 2970, Apr. 30, 1694; No. 3077, May 9, 1695; No. 3196, June 29, 1696; No. 3283, Apr. 29, 1697 ; No. 3430 , Sept. 26, 1698; No. 3494, May 8, 1699.

Colophon: Printed by Tho. Newcomb in the Savoy (Nos. 129-2365); Printed by Edw. Jones in the Savoy (Nos. 2366-24I7).

Supersedes the Oxford Gazette [q.v.] (from No. 24)

By Henry Muddiman, Charles Perrot.

At least two numbers of The London Gazette were reprinted in the American colonies before the appearance of a regular colonial newspaper, an issue of Feb. 9, 1684/85 printed by Samuel Green in Boston, and one in 1696 by William Bradford of New York. Many American papers which wished to assume semi-official or authoritative positions employed the term "Gazette" thus recognizing the prestige of the London Gazette in its position as an official paper."

The editorship of The London Gazette today is a government appointment. It is still published by authority and is the appointed organ for all announcements of the Executive.

The London post, communicating the high counsells of both Parliaments in England and Scotland, and all other remarkable passages, both Civill and martiall in his weekly travells through the three kingdomes. Printed and entered according to order. W. Nos. I- , D I 4/3I, 1646-F 26, $1647 / /$ ?

No. I, Dec. 31, 1646 Photostat

Colophon: Printed for H.B.

This is evidently a revival according to the announcement in No. I: "Thus wet and weary as he is, the CITY Post doth againe present himself unto you. .... After almost a years absence he comes on his old Errand, which is to bring you weekly Intelligence, and this (for the most part) being far saught, and elabourately sought, he doth hope will prove more acceptable ... : One thing he will promise you, and in this you may be confident, that he will be carefull to give you no more Newes than Truth, which (in the first place) in Papers of this Nature is much, and Newes indeed."

4 See Mott, F. L. American Journalism. New York, 194r, pp. 8, 15. 
The Man in the moon, discovering a world of knavery under the sun, with a perfect nocturnal, containing several strange wonders out of the antipodes, magyland, feryland, greenland, tenebres, and other parts adjacent. Published for the right understanding of all the mad-merry-people in great bedlam. 1663 .

No. 2, May 12, 1663. Photostat

Colophon: Printed in the world in the moon for J. Jones, to delight all the mad merry people under the Sun, 1663 .

Mercurius \&c. Upon my life new borne, and wants a Name, 'Troth let the Reader then impose the same. Veridicus - . - - - I wish thee; if not so, bee - - - - Mutus, - . - . - for wee lyes enough doe know. w. Jan. 17, 1644. Photostat

No imprint.

Announcement made in issue: "In briefe, I have a pretty boy, an Apis (?), come to me, that tenders his service under the title of a Mercury, as yet anonimus; but whether I shall entertatine the Fly, or not, I cannot tell; first I referre him to the Reader, if you like him, say so, and call him (pray) Verdicus; and he shall wait upon you weekely: If you like him not, decry him; and I shall soone dismisse the same ..."

Mercurius Anglicus. Communicating intelligence from all parts of the kingdome of England cheifly (sic.) from Westminster, London, Colchester, Duke Hambleton, and Sir Marmaduke Langdale. Printed in the yeare 1648 .

No. 1, Aug. 3, 1648. Photostat

Mercurius Aquaticus, communicating intelligence from all parts of the kingdome, especially from the navy. Printed in the yeare 1648 .

Aug. I1, 1648. Photostat

This issue is unnumbered.

. . Mercurius Civicus. Londons intelligencer or, Truth impartially rolated from thence to the whole kingdome, to prevent misinformation. w. Nos. I- , My 4/I I, 1643-Dec. I0, $1646 / /$.

No. 152, Apr. 30, 1646. Photostat

At head of title: Wood-cuts of Charles Rex and Sir Thomas Fairfax. Colophon: London, Printed for Tho. Bates at the signe of the Maydenhead on Snow-hill neere the Conduit, and I. W. in the Old-baily. I646. Entered in S.R., I, 227: "Tho. Bates and John Wright. Entred ... under the hand of Master Mabbott ..."

Mercurius Diutinus, collector of the affaires of Great Britaine: and martiall proceedings in Europe. w. Nos. I-I I, N 25/D 2, I646-F 3/10, $1647 / /$. 
Nos. 10-I I, Feb. 3-10, 1647. Photostat copies

Colophon: This is Printed according to Order for F. L. (No. 10)

Supersedes Diutinus Britanicus (from No. 3)

Mercurius dogmaticus communicating the proceedings at Westminster, at London, and the Head-quarters, with all other remarkable passages happening throughout the whole kingdome. w. Nos. I-4, Ja 6/1 $3-\mathrm{F}_{3}$, $1648 / /$.

No. I, Jan. 13, 1648. Photostat

Motto: "For God and King Charles." (No. I, p. 2.)

Mercurius politicus, comprising the sum of foreign intelligence, with the affairs now on foot in the three nations of England, Scotland, \& Ireland. For information of the people. w. Nos. I-6 I5, Je 6, I650-Ap 12, 1660//. Vol. [8], Nos. 552, [558], 572, 579, 589-593, [606], Feb. 3, Mar. I 7, June 23, July 21, Oct. 6-Nov. 10, 1659; Feb. 9, I66o.

Variations in sub-title: Comprising the summ of all intelligence, with the affairs, and designs now on foot, in the three nations of England, Ireland, and Scotland. (Until Vol. [7], No. 277, Oct. 4, 1655); Addition of the words Published by order of Parliament to Nos. 57259I, and Published according to order to Nos. 592-3, 606.

Colophon: Printed by Tho. Newcomb, living in Thames-street, over against Baynards-Castle.

Entered in S.R., II, 21 3, 220, 231-32, 247, 255: "Master Tho. Newcomb. Entred . . . by licence of Master Secr Thurloe ..." (Nos. 552, 558); "Master Tho. Newcomb. Entred . . . by licence of ye Parliament ..." (Nos. 572, 579); "Master Tho. Newcomb. Entred ... by authority ..." (Nos. 589-593); "Master Tho. Newcomb. Entred ... by licence of ye late Parliamt ..." (No. 606).

Mercurius populus. Or newes declaring plain truth to the people. No. I, $N$ I $1,1647 / /$.

No. I, Nov. I I, 1647. Photostat

No imprint.

In his last paragraph the author makes a farewell plea: "If I can get abroad the next week, I purpose to tell you some newes from the head or foote quarters, I care not whence it come, so it be good, but if you heare no more of me for a longer time, I pray faile not so to peruse this till yee doe; as yee may make it yours rather by reading, then only by buying; for it is one of your usuall faults to harken more after newes and new books, then to make a profitable use of the ould. Farewell till the next." 
Mercurius pragmaticus, communicating intelligence from all parts, touching all affaires, designes, humors, and conditions throughout the kingdome. Especially from Westminster, and the Head Quarters. w. Nos. I- , $\mathrm{S} \mathrm{I}_{4} / 2 \mathrm{I}, \mathrm{I} 647$-?

No. 12, Dec. 7, 1647

No imprint.

Mercurius publicus: Comprising the sum of forraign intelligence; with the affairs now in agitation in England, Scottland, and Ireland. For information of the people. Printed by order of the Council of state. w. Ja 5, I $660-S_{3}, 1663 / /$.

Vol. [I], Nos. 16-2 I, 23, 25-[26]-27, 31-32, Apr. 19-May 24; June 7; June $21-J u l y ~ 5$; Aug. 2-9, 1660 .

Vol. [II], Nos. [16]-1 7, 20, [22-25], Apr. 25-May 2, 23; June 6-27, I661.

Vol. [III], No. [37], Sept. I8, I662.

Other copies:

Vol. [I] Nos. 19, 23, 25, 32, May 10, June 7, 21, Aug. 9, I66o.

Variations in sub-title: Published by order (Vol. I, Nos. 31-32) replaces Printed by $\mathcal{E}^{2} c$.; Beginning with Vol. II, No. I, Io Jan. I66I, issued as: Mercurius Publicus. Comprising the sum of all affairs now in agitation in England, Scotland, and Ireland. Together with forraign intelligence for information of the people and to prevent false news. Published by authority.

Colophon: London, Printed by Tho. Newcomb, living in Thames-Street over against Baynards Castle (Vol. I, No. 16); London, Printed by John Macock and Tho: Newcomb (Nos. I7-32); London, Printed by Richard Hodgkinsonne, living in Thames-Street, over against Baynards-Castle (Vol. II, No. I6); London, Printed by Da. Maxwell, living in Thames-street, near Baynards Castle (Nos. 17-23); London, Printed by Richard Hodgkinson living in Thames-Street over against Baynards Castle (No. 24; Vol. III, No. 37).

Announcement made in Vol. I, No. I6: "Whereas Marchemont Nedham, the author of the weekly news books, called Mercurius Politicus, and the Publique Intelligencer, is, by Order of the Council of State, discharged from writing or publishing any publique intelligence: The Reader is desired to take notice, that by Order of the said Council, Henry Muddiman, and Giles Dury, are authorized henceforth to write and publish the said Intelligence, the one upon the Monday, and the other upon the Thursday; which they do intend to set out under the Titles of the Parliamentary Intelligencer, and Mercurius Publicus." Entered in S.R., II, 260, 263-4, 268, 280: "Master Thomas Newcomb. 
Entred ... by licence of the Councell of State ..." (Vol. I, No. I6-I 7) ; "Master John Macocke and Master Tho. Newcomb. Entred ... by licence of ye Councell of State ..." (Nos. I 8-20); "Master John Macock and Master Tho. Newcomb. Entred ... by order of the late Councell of State ..." (Nos. 2 I-26); "Master John Macocke and Master Tho. Newcomb. Entred . . . by order . . ." (Nos. 27, 31-32).

The New anti-Roman pacquet: or, Memoirs of Popes and Popery since the tenth century. w.

Nos. I [undated], 2-4, July I6-30, 1680.

Colophon: Printed for L. C. [Langley Curtiss].

The last leaf of each issue contains a section, unnumbered and undated, with caption-title: The Popes harbinger. By way of diversion.

Supersedes: The Weekly pacquet of advice from Rome [q.v.]

Superseded by: The Anti-Roman pacquet ... [q.v.]

The Observator. By Roger L'Estrange. Vols. I-3, Ap. I3, I68I- Mr. 9, I $687 / /$.

Vol. I, Nos. 1-470, Ap. I3, I68I-Jan. 9, I684.

Vol. II, Nos. I-21 5, Jan. I0, 1684-Feb. 7, 1685.

Vol. III, Nos. I-246, Feb. I I, I685-Mar 9, I687.

Variations in sub-title: Observator in question and answer (Vol. I, Nos. I-29); The Observator, in dialogue (Nos. 30-I I 2 ).

Colophon: London, Printed for Joanna Brome, at the Gun in S. Pauls Church-yard (Vol. I, Nos. 2, 9, 13-53, 55, 57-140, 142-398, 400-4I 7, 4I 9-423, 425-45, 447-70); London, Printed for Charles Brome, at the Gun in St. Pauls church-yard (Nos. 1, 7-8, 54, 56, I $41,399,418,424,446)$; London, Printed for H. Brome, at the Gun in S. Pauls Church-yard (Nos. 4-6, I0-1 2); London, Printed for Joanna Brome ... (Vol. II, Nos. I-34); London, Printed for Charles Brome at the Gun in St. Pauls Church-yard, and William Abington near the Wonder-Tavern in Ludgate-Street (Nos. 35-44); London, Printed for W. Abington, near the Wonder-Tavern in Ludgate-street (Nos. 45-I 30); London, Printed for Charles Brome ... (Nos. I 31-2 I5; Vol. III, Nos. I-246)

Each volume contains a title-page, as follows: Vol. I. The Observator in dialogue. By Roger L'Estrange. London, Printed by $\mathrm{J}$. Bennet, for William Abington, near the Wonder-Tavern in Ludgate Street. MDCLXXXIV. Frontispiece engraving of Roger L'Estrange; Vols. II \& III, The Observator, in dialogue. By Sir Roger L'Estrange, Kt.

\footnotetext{
${ }^{5}$ For life-span and history of this periodical, see entry: The Weekly pacquet of advice from Rome....
} 
London, Printed by J. Bennet, for Charles Brome, at the Gun in St. Paul's Church-yard. MDCLXXXIV (v. 2) MDCLXXXVII (v. 3).

L'Estrange states the purpose of the Observator in Vol. I, No. I, as follows: "My business is, to encounter the Faction, and to vindicate the Government; to detect their Forgeries; to lay open the Rankness of their Calumnies, and Malice; to Refute their Seditious Doctrines; to expose their Hypocrisy, and the bloudy Design that is carry'd on, under the Name, and Semblance, of Religion; And, in short, to lift up the Cloke of the True Protestant (as he Christens himself) and to shew the People, the Jesuite that lies skulking under it."'

To the query, "Shall the Observator be a weekly paper, or how?" L'Estrange answers: "No, no; but oftner, or seldomer, as I see Occasion."

The Oxford gazette. Published by authority. Oxford. semi-w. Nos. I-23, $\mathrm{N}$ I665-F I, I666//.

No. 4 , Nov. 27,1665 .

Colophon: Oxford, Printed by Leonard Liechfield, and Reprinted at London by Tho. Newcomb over against Baynards-Castle in ThamesStreet. 1665 .

Continued as The London gazette [q.v.] (from No. 24, Feb. 5, I666).

A Pacquet of advice from Rome: or, The history of Popery.

[Vol. I], No. I, Dec. 3, 1678.

Colophon: Licensed. Printed for C.L. 1678 .

The last leaf contains a section, unnumbered, but dated as above, with caption-title: The Popish courant.

Continued as The Weekly Pacquet of advice from Rome... [q.v] (from No. 2)

The Popes harbinger.

See: (1) The Anti-Roman pacquet... ; (2) The New anti-Roman pacquet....

The Popish courant.

See: (I) A Pacquet of advice from Rome ... ; (2) The Weekly pacquet of advice from Rome....

The Publick intelligencer communicating the chief occurrences and proceedings within the dominions of England, Scotland, and Ireland. Together with an account of affairs from severall parts of Europe. w. Oct. 8, 1655-Apr. 9, 1660//.

Nos. 161-166, Jan. 31-March 7, 1659. 
Colophon: London, Printed by Tho. Newcomb over against BaynardsCastle in Thames-street.

Entered in S.R., II, 254: "Master Tho. Newcomb. Entred . . by licence of the Parliamt ..."

The Scotch intelligencer, or The Weekely newes from Scotland and the Court.

Oct. 17-25, 1643. Photostat copies

Colophon: This is Licensed and entered according to Order.

The above issues are unnumbered, but probably are Nos. 1-2.

Supersedes: The Scottish mercury [q.v.]

Announcement made in the issue of Oct. 13-17: "Though I come Post with my Intelligence yet $I$ have much ado to get hither in time, for there is such a crowd of Diurnalls, Mercuries, and Aulicusses that presse in every week, that I can scarce get thorough, yet I thinke my honest brethren of England will make way for me, for I come for their good, and I bring good tydings; I can tell you both what they doe at Edinburgh, and at Oxford, for I have many a private Intelligencer, ..."

The Scottish mercury. Relating the weekely intelligence from Scotland and the Court. No. I, Oct. 13, 1643//.

[No. I, Oct. I3, I643]. Photostat

Colophon: This is Licensed and entered according to order.

This issue is unnumbered and undated.

Superseded by: The Scotch Intelligencer [q.v.]

In S.R., I, 79, under I3 October 1643 we find: "Hum. Blunden. Entred ... under the hand of Henry Walley a pamphlet called The Scotch mercury, $\mathcal{E}^{2} c$." which is probably this periodical in spite of title variation.

A True and impartial account of the Remarkable accidents casualties and other transactions happening in City and country, \&c. With allowance. Nos. I-I I, 1688//.

Nos. 9-II, July 28, Aug. 8, 25, 1688. Photostat copies

Colophon: London, Printed for J. C. near Fleet-Bridge, 1688.

Issued irregularly.

The Weekly discovery of the mystery of iniquity: in the rise, growth, methods, and ends of the late unnatural Rebellion in England, Anno I641. w. Nos. I-30, F 5-Ag 27, 1681//.

No. 5, March 5, 1681 .

Colophon: London, Printed for Benj. Tooke, $168 \mathrm{r}$. 
The Weekly pacquet of advice from Rome: or, The history of Popery. w. v. I-6 No. $3, \mathrm{D} 3,1678-\mathrm{F} 8,1689 / /$.

Vol. I, Nos. I-3I, Dec. 3, I678-July 4, I679.

Vol. II, Nos. I-44, July I I, I679-May 7, I680.

Vol. III, Nos. I-4, June 4-25, I68o.

Vol. III, Nos. 5-25 (numbered I-2I), July I6-Nov. 26, 1680.

Vol. III, Nos. 22, alias 26-80, Dec. 3, I68o-Dec. 16, I68I.

Other copies:

Vol. I, Nos. 2-3I, Dec. Io, I678-July 4, I679.

Colophon: London, Printed for C. L. (Vol. I, Nos. 2-I3, 2I-22); Printed for L. C. (Vol. I, Nos. 14-20, No. 23-Vol. III, No. 4); Printed for Langley Curtis (Vol. III, Nos. 22, alias 26-80).

Licensed.

Volume I has an imposing title-page and is quoted in full: "The Weekly pacquet of advice from Rome: or, The history of Popery. A Deduction of the Usurpations of the Bishops of Rome, and The Errors and superstitions by them from time to time brought into the Church. In the Process of which, The Papists Arguments are answered, their Fallacies Detected, their Cruelties Registred, their Treasons and seditious Principles Observed, and the whole Body of Papistry Anatomized. Perform'd by a Single Sheet, Coming out every Friday, but with a continual Connexion. To each being added, The Popish Courant: or, Some occasional Joco-serious Reflections on Romish Fopperies. . . . London: Printed for, and are to be sold by Langley Curtis, on Ludgatehill, either singly any Sheet by it self, or Whole Sets, containing them all together since they first came out. 1679."

The last leaf of each issue contains a section, dated but unnumbered, with caption-title: The Popish courant (Vol. I, No. 2-Vol. II, No. 44); A section, undated and unnumbered, with caption-title: The Popish courant (Vol. III, Nos. I-4); The Popish currant (Vol. III, Nos. 22, alias 26-37); The Popish courant (Vol. III, Nos. 38-40, 42, 45, 46, 48, 5 I, 53, 54); The Courant (Vol. III, Nos. 4I, 43-4, 47, 49, 52, 55-80); The Protestant courant (Vol. III, No. 50).

Title variations: Vol. I, No. I, Dec. 3,1678 , issued as $A$ Pacquet of advice from Rome ... [q.v.]; Vol. I, No. 2-Vol. III, No. 4, Dec. 10, 1678-June 25, 1680, issued as The Weekly pacquet of advice from Rome: or, The history of Popery; [Vol. III, Nos. 5-8], Numbered I-4, [No. I, undated], Nos. 2-4, July 16-30, 1680, issued as The New anti-Roman pacquet: or, Memoirs of Popes and Popery since the tenth century [q.v.]; [Vol. III, Nos. 9-25], Numbered 5-2 I, Aug. 6Nov. 26, 1680, issued as The Anti-Roman pacquet: or, Memoirs of Popes EO Popery... [q.v.]; Vol. III, Nos. 22, alias 26-37, Dec. 3, 
I680-Feb. I8, I68I, issued as The Weekly pacquet of advice from Rome Restored: or, The history of Popery continued; Vol. III, Nos. 38-80, Feb. 25-Dec. 16, 168 I, issued as The Weekly pacquet of advice from Rome: or, The history of Popery.

Pagination starts afresh: Vol. II, No. I, July I I, I679; Vol. III, No. I, June 4, 1680; [Vol. III, No. 5], Numbered I, undated, No. 2, July 16, i68o.

Note: Vol. II is incomplete in that Nos. 45-47, May 14-28, I68o are lacking.

Note: The issue of Dec. 3, I68o, Vol. III, No. 22, alias 26, is marked, "p. [I69 alias 20I]," and pagination continues from the alias number, thereby omitting use of numbers $169-200$ and allowing for duplication of page numbers $1-32$ used in Vol. III, 1680. 